\title{
Challenges and Barriers to HIV Care for Mexican Born Men Living in Chicago
}

\author{
Patricia Aguado $^{1,2}$ (1) Susan Ryerson-Espino ${ }^{2} \cdot$ Pamela Vergara-Rodriguez $^{3}$
}

Accepted: 30 January 2021

(c) The Author(s) 2021

\begin{abstract}
Background: Latinx men are disproportionately impacted by HIV. Research often looks at Latinx people as a heterogeneous population. This paper describes baseline characteristics and barriers to HIV care among Mexican born men enrolled in an HIV care engagement intervention at a public health clinic in Chicago. Methods: Survey and medical chart data were collected. Results: 66 Mexican born men enrolled in the project. Over half (60\%) were newly diagnosed; $40 \%$ were reengaging in care or establishing care for the first time. Participants reported significant pre and postmigration concerns including poverty, social stigma, late entry to care, and concurrent health concerns, including $47 \%$ screening positive for depression. Barriers to care and mental health concerns were significantly related to Stage 3 HIV. Discussion: More prevention and intervention research is needed to ameliorate the negative socioeconomic and health ramifications of immigration and bolster mental and sexual health, reduce HIV transmission, and increase testing, linkage and care retention.
\end{abstract}

Keywords Mexican $\cdot$ Latino/x $\cdot$ Mental health $\cdot$ Barriers $\cdot$ People living with HIV $\cdot$ Men

\section{Background}

Next to Black Americans, Latinxs are the group most impacted by HIV in the United States; they have lower levels of HIV care retention, lower HIV viral suppression rates and experience HIV related deaths two times higher than do non-Latinx Whites [1]. Among Latinxs, between 2010 and 2016, new HIV diagnoses increased by $10 \%$, retention in HIV medical care increased for all other racial/ethnic subgroups but remained the same for Latinxs, and while Latinxs make up $18 \%$ of the total population, they accounted for $28 \%$ of new infections nationally [1,2].

In 2017, Illinois was seventh among the states reporting the highest number of HIV diagnoses [3]. The city of Chicago carries the burden of HIV in Illinois and is home

Patricia Aguado

paguado@neiu.edu

1 Department of Social Work, Northeastern Illinois University, 5500 North St. Louis Avenue, Lech Welesa Hall, Chicago, IL 3043, USA

2 The Ruth M. Rothstein CORE Center, Hektoen Institute of Medicine, Chicago, IL, USA

3 Cook County Bureau of Health Services, The Ruth M. Rothstein CORE Center, Chicago, IL, USA to roughly 24,000 people living with HIV/AIDS (PLWHA) [4]. Men in Chicago accounted for 5.2 times as many new HIV diagnoses when compared to women, men who have sex with men (MSM) accounted for the majority (72.2\%) of new HIV diagnoses, and men were significantly more likely to present with late-stage HIV diagnosis (defined as having AIDS at the time of initial HIV diagnosis or being diagnosed with AIDS within 12 months of initial diagnosis) $[4,5]$. Latinxs accounted for $22 \%$ of new HIV diagnoses and made up $24 \%$ of those presenting with late-stage HIV diagnoses. Given the incidence and prevalence of HIV among the Latinx community nationally and locally in Chicago, it is important to have a better understanding of the driving factors of HIV/AIDS and linkage and retention to care among Latinx subgroups, like Mexican immigrant men.

The prevalence of depression, anxiety and substance use have long been recognized as influential in the linkage and retention and overall quality of life of people living with HIV/ AIDS (PLWHA), including Latinxs [6-8]. Foreign-born Latinx PLWHA often bear the added hardships of migration stress and trauma $[9,10]$. Mexican-born individuals living in the US are more likely to endure economic challenges, lack health insurance and immigration documentation, experience language and other barriers to care as well as inferior HIVrelated outcomes [11-13]. Moreover, this group is more likely 
to have experienced trauma before and during migration to the United States. Sociocultural factors such as lack of HIV knowledge, health care practices carried over from Mexico, work schedules, Machismo, stigma related to homosexuality, and internalized homophobia also present challenges to the identification and retention of individuals living with HIV [12, 13]. HIV alone may not be the major challenge Mexican immigrants experience, but rather the interplay of mental health issues, sociocultural and structural barriers contribute collectively to health disparities affecting Latinx PLWHA [11-14]

Much of what is known about HIV among Latinx communities is broad in scope; when researching immigrants, Latinxs are often grouped together without focus on any specific subgroup. This paper's aim is to add to the literature by describing the characteristics and barriers to HIV care and retention for Mexican immigrant men living in Chicago.

\section{Conceptual Framework}

Ecological Systems Theory informed the conceptual framework for this study. Specifically, we aimed to explore multilevel barriers to engagement in HIV care work including interpersonal, community and structural barriers [15].

\section{Description}

In September 2013, the Cook County Health and Hospital Systems (CCHHS), Ruth M. Rothstein CORE Center was one of ten sites nationally funded by the Health Resources and Services Administration (HRSA), Special Project of National Significance (SPNS) to develop a transnationallyinformed intervention whose focus was to better understand and address HIV care continuum barriers for a Latino subpopulation. Proyecto Promover was born out of this opportunity and aimed to understand multi-level barriers to care and increase the identification, engagement, and retention in care of Mexican-identified individuals living with HIV in Chicago.

The current study highlights lessons learned from baseline data which were used as an early step to individualizing the patient-centered navigation that formed the primary clinicbased intervention component of Proyecto Promover. Baseline data also provide an important highlight of barriers facing low income Mexican identified individuals seeking care in Chicago and may be informative for the development of other prevention and care engagement interventions within Chicago and in other cities with similar populations.

\section{Methods}

\section{Eligible Participants}

Proyecto Promover was a prospective study of Mexican identified individuals of all gender identities living with HIV in Chicago and the surrounding areas. Participants were enrolled between January 2015 and October 2017 from an HIV primary care clinic in the city of Chicago. Eligibility criteria included: self-identifying as Mexican; aged 18 years or older; and, newly diagnosed with HIV (within the past six months) or not optimally engaged in care (diagnosed more than six months ago and no HIV primary care visits in the last six months). Participants did not have to be literate but had to be able to speak English or Spanish and provide verbal consent. For the purpose of this study we limited participation to Mexican-identified, born in Mexico, self-identified men.

\section{Data Collection}

Baseline data were gathered via two methods. A computerassisted self-interview (ACASI) developed by the national evaluation and technical assistance center (ETAC), at the University of California at San Francisco (UCSF) and local structured interviews between clinical navigators and patients. The current study also involved baseline medical chart data. All survey instruments and interview protocols were either published Spanish versions or locally translated from English to Spanish, then back translated from Spanish to English by a certified local Mexican-identified translator. This study was approved by the Institutional Review Boards at the CCHHS and the UCSF ETAC.

\section{Measures}

The multisite baseline quantitative survey was administered at the time of consent or soon thereafter most typically at the time of a first clinical linkage appointment. This survey elicited demographics including age, preferred gender, education, marital status, income, insurance, sexual attraction, and sexual orientation. This survey also elicited transnational experiences including birthplace, travel between Mexico and the United States, age of first migration, English and Spanish language proficiencies, and remittances. Local sites were able to incorporate a few measures into the ACASI; local Proyecto Promover items explored immigrant stressors, family separations, and exposure to domestic violence. Proyecto Promover's intervention and evaluation team members reviewed the Hispanic Stress Inventory [16] and identified items for inclusion and adaptation. Ultimately six 
items explored premigration economic stressors, four items explored premigration social stigma, five explored journey trauma, and two items explored postmigration housing (appended). Participants were asked to identify using a checklist any family and significant friend separations of one year or more, as a result of living in the USA. Participants were also asked to report current and past exposure to intimate partner violence adapted from a Women of Color HRSA-SPNS initiative [17].

In addition to the ACASI, participants and the clinical navigators met to discuss the intervention and explore barriers to care. These interviews occurred within the first 2 months of their engagement in care and helped individualize the patient-centered navigation intervention. This local structured interview included the Primary Care PTSD Screen [18], the Center for Epidemiologic Studies Depression Scale (CES-D) [19], the CAGE questionnaire [20], and a barriers inventory, also adapted from a Women of Color HRSA SPNS initiative [17] that explored barriers to care including awareness of resources, coping with HIV and treatment, and HIV stigma. All scales used in this study were found to have acceptable internal reliability as measured by Cronbach's alpha as reported in Tables 2 and 3, along with computation of scale scores.

Medical chart data reviewed included date of diagnosis, care continuum status (newly diagnosed or not optimally engaged in care) and clinical characteristics at linkage to clinic: viral load, CD4, presence of opportunistic infections (OIs), concurrent syphilis, and if participant was referred to intervention from an acute care setting.

\section{Data Analysis}

Data were merged and analyzed using IBM SPSS Statistics 26. Descriptive statistics (means, medians, standard deviations, ranges, averages, and frequency distributions) were used to understand baseline characteristics. Measures of association, test of normality and independent samples $t$ test were used to explore relationships between baseline characteristics, specifically demographic, transnational and clinical variables.

Months since diagnosis was computed using dates of diagnosis and consent and helped validate care continuum status. Age of migration and diagnosis were compared to determine likely country of transmission (U.S. if after the date of migration). Suppression was identified for all with viral loads $<200 \mathrm{~mL}$. Stage $3 \mathrm{HIV}$ was determined by reviewing the length of time since diagnosis, CD4 counts, and OIs documented in the medical record. Specifically, Stage 3 was identified when diagnosis $<3$ months and CD4 counts $<350$ or there was evidence in the medical record of OIs.

\section{Results}

\section{Baseline Demographic Characteristics}

Between January 2015 and July 2017, 66 Mexican identified and born men enrolled in Proyecto Promover and completed the baseline survey. Participants were on average 38 years old; only $35 \%$ completed high school or higher in education. Of those reporting income, three quarters (78\%) reported income below $\$ 11,491$ (single adult federal poverty line in 2013 when study was designed) and were largely uninsured (62\%). The majority (74\%) appeared to be stably housed within the six months prior to baseline. The majority of participants identified as single (60\%); $70 \%$ of the men endorsed sexual attraction to men (20\% some to $50 \%$ mostly/ only attracted to males). Relative to sexual orientation, $24 \%$ did not make a selection and an additional $6 \%$ endorsed "other" indicating that terms used may not be recognized/ accepted; 36\% identified as gay, 17\% endorsed "straight", and $15 \%$ as "bi" Table 1.

\section{Transnational Experiences}

All study participants (100\%) were immigrants from Mexico arriving in the U.S. on average 17 years ago at an average age of 21 years. The majority of participants $(73 \%)$ reported never traveling to Mexico; $97 \%$ reported family separations, most commonly from parents (77\%); $80 \%$ reported occasional to regular remittances to family back in Mexico; English language proficiency varied; one quarter (24\%) reported speaking English well to very well; the majority (97\%) reported speaking Spanish well to very well. The vast majority (93\%) reported at least some economic concerns in Mexico, 65\% reported at least some social stigma in Mexico, and $47 \%$ reported being exposed to at least one trauma during journey(ies) to the United States. Over half (62\%) reported at least some exposure to poor housing conditions in the states Table 2.

\section{Baseline Clinical Characteristics and Barriers to Care}

The US appeared to be the country of transmission for the majority of participants (95\%). The average age of diagnosis was 36 years. Over half (68\%) were newly diagnosed, and the remaining $32 \%$ were returning to care or engaging in care for the first time with an HIV diagnoses of more than 6 months. Half (50\%) were referred to the program from acute care settings. Only $9 \%$ were virally suppressed at baseline; $35 \%$ had documented opportunistic infections (OIs); and 26\% concurrent Syphilis. Of those diagnosed within 3 months of consent, $82 \%$ were Stage 3 (with CD 4 


\begin{tabular}{|c|c|}
\hline Variables & Descriptive statistics $(n=66)$ \\
\hline Current age & $\mathrm{m}=38.2(\mathrm{sd}=8.4)$, range $22-63$ \\
\hline Preferred Gender Cis Men & $100 \%(66)$ \\
\hline Education I haven't gone to school & $1.5 \%(1)$ \\
\hline Grade 4 or less & $9.1 \%(6)$ \\
\hline Primary and two years of secondary (5th-8th) & $33.3 \%(22)$ \\
\hline Third year of secondary and two years of prep (9-11) & $21.2 \%(14)$ \\
\hline Grade 12 or GED (or prep exam) & $24.2 \%(16)$ \\
\hline Some college, associates or technical degree & $9.1 \%(6)$ \\
\hline Bachelors degree & $1.5 \%(1)$ \\
\hline Marital status single & $60.6 \%(40)$ \\
\hline In relationship - living together & $16.7 \%(11)$ \\
\hline In relationship - not living together & $13.6 \%(9)$ \\
\hline Married & $9.1 \%(6)$ \\
\hline Income in last 12 months $<\$ 600$ & $21.2 \%(14)$ \\
\hline$\$ 600-2900$ & $19.7 \%(13)$ \\
\hline$\$ 3000-5999$ & $15.2 \%(10)$ \\
\hline$\$ 6000-11,490$ & $10.6 \%(7)$ \\
\hline$\$ 11,491-15,282$ & $15.2 \%(10)$ \\
\hline$\$ 15,283-35,999$ & $3 \%(2)$ \\
\hline Don’t know & $15.2 \%(10)$ \\
\hline Homelessness/Housing instability in last 6 months never & $74.2 \%(49)$ \\
\hline Rarely or only a few times & $13.6 \%(9)$ \\
\hline Sometimes & $10.6 \%(7)$ \\
\hline Often & $1.5 \%(1)$ \\
\hline Insurance No & $62.1 \%(41)$ \\
\hline Yes & $33.3 \%(22)$ \\
\hline Don’t know & $4.5 \%(3)$ \\
\hline Sexual attraction only females & $30.3 \%(20)$ \\
\hline Mostly males & $25.8 \%(17)$ \\
\hline Only males & $24.2 \%(16)$ \\
\hline Equally males \& females & $12.1 \%(8)$ \\
\hline Mostly females & $7.6 \%(5)$ \\
\hline Sexual orientation gay & $36.4(24)$ \\
\hline No selection & $24.2 \%(16)$ \\
\hline Straight & $16.7(24)$ \\
\hline Bisexual & $15.2 \%(10)$ \\
\hline Multi (gay and bisexual) & $1.5 \%(1)$ \\
\hline Other & $6.1 \%(4)$ \\
\hline
\end{tabular}

counts $<350$ or OIs). Just under one third (30\%) reported past or current intimate partner violence concerns; $52 \%$ screened positive for depression and $14 \%$ screened positive for PTSD. Over half (65\%) screened positive for alcohol concerns, $23 \%$ for drug concerns, and participants endorsed on average 9 out of 24 barriers to care Table 3 .

More than half reported barriers to care relating to fatalism, stigma and denial. Specifically, $79 \%$ endorsed believing HIV was a death sentence; $73 \%$ endorsed not being ready to accept diagnosis; $70 \%$ endorsed fearing judgment; $71 \%$ endorsed fear of discrimination; $61 \%$ endorsed not feeling sick, and 55\% endorsed not wanting to be seen receiving care in an HIV clinic Table 4.

\section{Characteristics Associated with Barriers to Care and Stage 3 HIV}

Correlations were explored between barriers total score and demographic, transnational and clinical variables. Higher barrier reports were significantly associated with higher premigration economic concerns $(\mathrm{r}=0.35, \mathrm{p}<0.01)$, positive PTSD screen $(\mathrm{rpb}=0.29, \mathrm{p}<0.05)$ and positive depression screen $(\mathrm{rpb}=0.27, \mathrm{p}<0.05)$ as well as importantly Stage 3 recruitment $(\mathrm{rpb}=0.38, \mathrm{p}<0.05)$. Upon further exploration, we found a significant association between mental health concerns and Stage 3 HIV (Fisher's Exact Test, $\mathrm{p}<0.05$ ). All of the newly diagnosed participants recruited within 
Table 2 Transnational experiences

\begin{tabular}{|c|c|}
\hline Variable & Descriptive statistics $(n=66)$ \\
\hline Birthplace Mexico & $100 \%(66)$ \\
\hline Age of first migration $(n=77)$ & $\mathrm{M}=21.1 \mathrm{yrs}(\mathrm{SD}=6.2)$, Range $4-39$ \\
\hline $\begin{array}{l}\text { Travel to Mexico Never } \\
\text { Rarely } \\
\text { Sometimes } \\
\text { Often }\end{array}$ & $\begin{array}{l}72.7 \%(48) \\
18.2 \%(12) \\
7.6 \%(5) \\
1.5 \%(1)\end{array}$ \\
\hline $\begin{array}{l}\text { Separations any family/close friend separation } \\
\text { One or more parents } \\
\text { Extended family } \\
\text { Close friend(s) } \\
\text { Immediate family (spouse and or children) }\end{array}$ & $\begin{array}{l}97 \%(64) \\
77.3 \%(51) \\
57.6 \%(38) \\
37.9 \%(25) \\
7.6 \%(5)\end{array}$ \\
\hline $\begin{array}{l}\text { Remittances occasionally } \\
\text { Regularly } \\
\text { No }\end{array}$ & $\begin{array}{l}56.1 \%(37) \\
24.2 \%(16) \\
19.7 \%(13)\end{array}$ \\
\hline English language proficiency (6 items, summed and averaged, Cronbach's $\alpha=.97$ ) & $\begin{array}{l}\mathrm{M}=2.2(\mathrm{SD}=.8), \text { Range } 1-4 \\
(26.2 \% \text { Well-Very Well })\end{array}$ \\
\hline Spanish language proficiency (6 items, summed and averaged, Cronbach's $\alpha=.94$ ) & $\begin{array}{l}\mathrm{M}=3.8 \text { (SD.4),Range } 2.7-4.0 \\
(94 \% \text { Well-Very Well) }\end{array}$ \\
\hline $\begin{array}{l}\text { Premigration economic stressors ( } 6 \text { items, summed and averaged, Cronbach's } \alpha=.76 ; 1 \text { "nunca" }-4 \text { "todo } \\
\text { el tiempo") }\end{array}$ & $\mathrm{M}=2.1(\mathrm{SD}=.7)$, Range $1-4$ \\
\hline Never & $7.6 \%(5)$ \\
\hline At least some economic concerns & $92.4 \%(61)$ \\
\hline $\begin{array}{l}\text { Premigration social stigma ( } 4 \text { items, summed and averaged, Cronbach's } \alpha=.89 ; 1 \text { "nunca" }-4 \text { "todo el } \\
\text { tiempo") }\end{array}$ & $\mathrm{M}=1.7(\mathrm{SD}=.9)$, Range $1-4$ \\
\hline Never & $34.8 \%(23)$ \\
\hline At least some social stigma & $65.2 \%(43)$ \\
\hline $\begin{array}{l}\text { Journey trauma ( } 5 \text { items, summed and averaged, Cronbach's } \alpha=.76 ; 1 \text { "nunca" }-4 \text { "todo el tiempo") } \\
\text { Never } \\
\text { Exposed to at least one trauma }\end{array}$ & $\begin{array}{l}\mathrm{M}=1.3(\mathrm{SD}=.5), \text { Range } 1-3.2 \\
53 \%(35) \\
46.7 \%(31)\end{array}$ \\
\hline $\begin{array}{l}\text { US housing conditions ( } 2 \text { items, summed and averaged, Cronbach's } \alpha=.79 ; 1 \text { "nunca" }-4 \text { "todo el } \\
\text { tiempo") }\end{array}$ & $\begin{array}{l}\mathrm{M}=1.6(\mathrm{SD}=.7), \text { Range } 1-4 \\
37.9 \%(25)\end{array}$ \\
\hline $\begin{array}{l}\text { Never } \\
\text { Exposed to at least some poor housing }\end{array}$ & $62.1 \%(41)$ \\
\hline
\end{tabular}

3 months of diagnosis who screened positive for depression also screened positive for PTSD $(n=18)$ and were identified with Stage 3 HIV. Barriers were normally distributed by Stage 3 HIV (Shapiro-Wilk, ns), and were found to be significantly higher for those identified with Stage $3 \mathrm{HIV}$ (Independent Samples t test (20.25) -3.88, $\mathrm{p}<0.01$. Those in Stage 3 HIV endorsed $57 \%$ more barriers than those not in Stage 3 HIV $\left[\mathrm{M}_{\text {Stage 3 }}=16.09(\mathrm{SD}=7.34) ; \mathrm{M}_{\text {Not Stage 3 }}=9.00\right.$ $(\mathrm{SD}=3.42)$ ]. Premigration economic concerns were not significantly associated with Stage 3 recruitment.

\section{Discussion}

This study adds to the literature on HIV linkage to care and care retention associated with migration and adaptation to living in the US, specifically depression, trauma, substance abuse and persistent socioeconomic stress [6, 7, 21]. Participants reported significant pre and postmigration concerns including poverty, social stigma, late entry to care or late stage HIV diagnosis, and concurrent health concerns, including $47 \%$ screening positive for depression. Depression and barriers to care were significantly related to Stage $3 \mathrm{HIV}$.

Individuals in our study endorsed multiple stressors associated with their HIV diagnosis including stigma, shame, and fatalismo Table 4. Close to half of our sample reported at least one traumatic incident during their migration to the U.S. and 14\% scored positive for PTSD. We did not explore on a deeper level other experiences of trauma, but given our findings, albeit limited in scope, we believe that the likelihood of delayed linkage and/or retention in HIV care is in part connected to the historical and complex trauma associated with migration and adaptation to the US including: social isolation, poverty, violence, discrimination, racism and fear of HIV illness [11, 12, 22, 23]. Further, identifying as a gay man or MSM coupled with the current anti-immigrant socio-political climate adds another layer of discrimination and potentially exacerbates symptoms of trauma, 
Table 3 Baseline clinical presentation

\begin{tabular}{|c|c|}
\hline Variable & Descriptive statistics $(n=66)$ \\
\hline Age of diagnosis & $\mathrm{M}=35.9$ yrs $(\mathrm{SD}=9.5)$, Range $0-59.6$ \\
\hline Months since diagnosis & $\mathrm{M}=33.1$ months $(\mathrm{SD}=61.2)$, Range $0-273.8$ \\
\hline $\begin{array}{l}\text { Care continuum status Newly diagnosed } \\
\text { Not optimally engaged }\end{array}$ & $\begin{array}{l}68.2 \%(45) \\
31.87 \%(21)\end{array}$ \\
\hline $\begin{array}{l}\text { Country of transmission US } \\
\text { At birth in Mexico } \\
\text { Close to time of migration prior to entry into US }\end{array}$ & $\begin{array}{l}95.5 \%(63) \\
1.5 \%(1) \\
3 \%(2)\end{array}$ \\
\hline Suppression rate at study entry & $9.1 \%(6)$ \\
\hline OIs prior to study entry & $34.8 \%(23)$ \\
\hline Syphilis at study entry & $25.8 \%(17)$ \\
\hline Stage 3 at study entry $(n=39)<3$ months from Dx with CD4 $<350$ and/or OI) & $82.1 \%(32 / 39)$ \\
\hline Acute care referral to intervention & $50 \%(33)$ \\
\hline \multicolumn{2}{|l|}{ Violence } \\
\hline I am currently facing violence and, or abuse that threatens my life & $-(0)$ \\
\hline I have some fears about my safety (emotional security, sexual, physical) & $16.7 \%(11)$ \\
\hline I have experienced abuse or domestic violence in the past & $13.6 \%(9)$ \\
\hline I have never experienced abuse or domestic violence & $69.7 \%(46)$ \\
\hline $\begin{array}{l}\text { CES-D (Total score across } 20 \text { items, Cronbach's } \alpha=.90 ; 0 \text { "Menos de un día” }-3 \text { "5-7 } \\
\text { dias") }(\mathrm{n}=66)\end{array}$ & $\begin{array}{l}\mathrm{M}=18.1(\mathrm{SD}=7.3), \text { Range } 9-38 \\
47.1 \%(40) \text { screened positive (scores of } 16 \text { or higher) }\end{array}$ \\
\hline $\begin{array}{l}\text { PTSD (Total score across } 4 \text { items, Cronbach's } \alpha=.80 ; 0 \text { "Nada", } 1 \text { "Algo", } 2 \text { "Mucho") } \\
{ }^{1}(\mathrm{n}=65)\end{array}$ & $\begin{array}{l}\mathrm{M}=.86(\mathrm{SD}=1.25), \text { Range } 0-4 \\
15.5 \%(13) \text { screened positive }\end{array}$ \\
\hline Alcohol substance abuse concerns (Cage; 4 Y/N items) $(n=65)$ & $\begin{array}{l}\mathrm{M}=1.2(\mathrm{SD}=1.1), \text { Range } 0-4 \\
58.8 \%(50) \text { screened positive (at least } 1 \text { or higher score) }\end{array}$ \\
\hline Drug abuse concerns (Cage; 4 items $Y / N)(n=65)$ & $\begin{array}{l}\mathrm{M}=.4(\mathrm{SD}=.9), \text { Range } 0-4 \\
23.5 \%(20) \text { screened positive (at least } 1 \text { or higher score) }\end{array}$ \\
\hline $\begin{array}{l}\text { Barriers to Care (Total score across } 24 \text { items, } \alpha=.79,0 \text { "Nada", } 1 \text { "Algo", } 2 \text { "Mucho", } \\
\mathrm{n}=66 \text { ) }\end{array}$ & $\begin{array}{l}\mathrm{M}=15.7(\mathrm{SD}=7.9), \text { Range } 2-38 \\
\text { Ave } 9.9 \text { barriers endorsed }(4.4) 1-21 \\
\text { all but } 1 \text { endorsed at least } 1 \text { barrier }\end{array}$ \\
\hline
\end{tabular}

which can lead to maladaptive coping [22, 23] and impact linkage and retention in HIV care [11, 12, 24, 25].

Participants also reported access and logistics barriers. Access to care can be largely contingent on insurance coverage. Insurance coverage, conversely, is largely contingent on employment in sectors that offer worker benefits and protections. The majority of participants in our study were presumed to be undocumented due to their migration details and thus not eligible for Medicaid, despite likely acquiring HIV in the United States. While individuals in Chicago can access HIV care independent of documentation status, the belief that this may be an eligibility requirement to access public health services can further complicate HIV care.

Most of the individuals in our study moved to the U.S. as young adults, in their late teens or early twenties. Adolescence and young adulthood are a universal period of risk taking and sexual exploration. Additionally, multiple studies point to migration as a source of sexual risk taking and vulnerability to HIV for Mexicans [9, 21, 26]. After migration, Mexican immigrants are more likely to have sex with multiple partners, engage in spontaneous sex, condomless sex and meet potential partners at bars [26, 27]. Over half of our sample also endorsed alcohol issues and nearly one quarter reported concerns with other substances, these behaviors collectively, migration and substance use, can elevate HIV risk $[7,8,21,28]$ and appears to be consistent with our findings that the majority of participants in this study appear to have acquired HIV after migration to the United States.

The convergence of all of these issues underscore the need to create programs that are holistic, inclusive and nuanced in scope. While understanding the social characteristics and barriers to care for Mexican immigrants is critical to helping achieve retention in care and viral suppression, understanding these issues alone and creating interventions that address these kinds of barriers are not enough to improve the lived experiences of this Mexican immigrant population.

More attention and advocacy efforts need to be geared towards dismantling the systems of oppression that made these individuals vulnerable to HIV to begin with and that continue to complicate their care retention. A focus on structural barriers, specifically anti-racism work, fighting against patriarchy or in this case machismo, health advocacy and immigration reform can help individuals feel accepted, grounded, safe and further, would support their efforts to 
Table 4 Barriers to care endorsement rate $\left(n=66^{*}\right)$

\begin{tabular}{|c|c|c|c|c|}
\hline Item Description & Nada/not at all & Algo/some what & Mucho/a great deal & $\begin{array}{l}\text { Endorsed } \\
\text { (somewhat to a } \\
\text { great deal) }\end{array}$ \\
\hline $\begin{array}{l}\text { Pensaba que mi diagnóstico era una sentencia de muerte. (I thought } \\
\text { my diagnoses was a death sentence.) }\end{array}$ & $21.2 \%(14)$ & $16.7 \%(11)$ & $62.1 \%(41)$ & $78.8 \%(52)$ \\
\hline $\begin{array}{l}\text { No estaba listo para aceptar mi diagnóstico. (I was not ready to } \\
\text { accept my diagnosis.) }\end{array}$ & $27.3 \%(18)$ & $16.7 \%(11)$ & $56.1 \%(37)$ & $72.8 \%(48)$ \\
\hline $\begin{array}{l}\text { Sentía que podía sufrir discriminación. (I felt I would suffer discrimi- } \\
\text { nation.) }\end{array}$ & $28.8 \%(19)$ & $21.2 \%(14)$ & $50 \%(33)$ & $71.2 \%(47)$ \\
\hline Pensaba que podría ser juzgado. (I thought that I would be judged.) & $30.3 \%(20)$ & $21.2 \%(14)$ & $48.5 \%(32)$ & $69.7 \%(46)$ \\
\hline No me sentía enfermo. (I did not feel sick, $n=64$ ) & $39.1 \%(25)$ & $17.2 \%(11)$ & $43.8 \%(28)$ & $60.9 \%(39)$ \\
\hline $\begin{array}{l}\text { No quería que alguien me viera recibiendo atención en una clínica } \\
\text { de VIH. (I did not want anyone to see me getting care from an HIV } \\
\text { clinic, } n=65 \text { ) }\end{array}$ & $44.6 \%(29)$ & $24.6 \%(16)$ & $30.8 \%(20)$ & $55.4 \%(36)$ \\
\hline $\begin{array}{l}\text { No sabía que existía un tratamiento disponible para mí. (I did not } \\
\text { know there was treatment available for me.) }\end{array}$ & $54.5 \%(36)$ & $25.8 \%(17)$ & $19.7 \%(13)$ & $45.5 \%(30)$ \\
\hline $\begin{array}{l}\text { No pensaba que el médico hablaría mi idioma. (I did not think the } \\
\text { doctor would speak my language.) }\end{array}$ & $54.5 \%(36)$ & $22.7 \%(15)$ & $22.7 \%(15)$ & $45.4 \%(30)$ \\
\hline Tenía miedo del tratamiento. (I was afraid of treatment.) & $54.5 \%(36)$ & $22.7 \%(15)$ & $22.7 \%(15)$ & $45.4 \%(30)$ \\
\hline $\begin{array}{l}\text { El trayecto a la clínica era muy largo. (The travel time to the clinic } \\
\text { was too long.) }\end{array}$ & $56.1 \%(36)$ & $25.8 \%(17)$ & $18.2 \%(12)$ & $43.9 \%(29)$ \\
\hline $\begin{array}{l}\text { No quería tomar mi medicina. (I did not want to take medication, } \\
\mathrm{n}=65 \text { ) }\end{array}$ & $60.0 \%(39)$ & $18.5 \%(12)$ & $21.5 \%(14)$ & $40.0 \%(26)$ \\
\hline $\begin{array}{l}\text { Pensaba que no podía conseguir atención médica. (I thought I could } \\
\text { not obtain medical attention.) }\end{array}$ & $62.1 \%(41)$ & $15.2 \%(10)$ & $22.7 \%(15)$ & $37.9 \%(25)$ \\
\hline No sabía a dónde ir. (I did not know where to go.) & $62.1 \%(41)$ & $19.7 \%(13)$ & $18.2 \%(12)$ & $37.9 \%(25)$ \\
\hline No tenía seguro médico. (I did not have medical insurance.) & $65.2 \%(43)$ & $16.7 \%(11)$ & $18.2 \%(12)$ & $34.9 \%(23)$ \\
\hline $\begin{array}{l}\text { Prefiero utilizar solo la atención de ER o Emergencia y no involu- } \\
\text { crarme con un proveedor médico regular. (I prefer to utilize care } \\
\text { only in the ER and not involve myself with a regular provider.) }\end{array}$ & $68.2 \%(45)$ & $10.6 \%(7)$ & $21.2 \%(14)$ & $31.8 \%(21)$ \\
\hline $\begin{array}{l}\text { Pensaba que podía tener problemas legales. (I thought I would have } \\
\text { legal problems) }\end{array}$ & $69.7 \%(46)$ & $12.1 \%(18)$ & $18.2 \%(12)$ & $30.3 \%(20)$ \\
\hline $\begin{array}{l}\text { No podía pagar por mi atención médica. (I could not pay for my } \\
\text { medical care.) }\end{array}$ & $71.2 \%(47)$ & $13.6 \%(9)$ & $15.2 \%(10)$ & $28.8 \%(19)$ \\
\hline $\begin{array}{l}\text { Tengo tendencia a no confiar en los proveedores médicos. (I have a } \\
\text { tendency to not trust medical providers.) }\end{array}$ & $71.2 \%(47)$ & $16.7 \%(11)$ & $12.1 \%(8)$ & $28.8 \%(19)$ \\
\hline $\begin{array}{l}\text { Tenía miedo de lo que mi pareja pudiera hacerme si descubría que } \\
\text { estaba recibiendo atención. (I was afraid what my partner would do } \\
\text { to me if he or she discovered out I was receiving care.) }\end{array}$ & $71.2 \%(47)$ & $7.6 \%(5)$ & $21.2 \%(14)$ & $28.8 \%(19)$ \\
\hline No contaba con medio de transporte. (I had no transportation.) & $72.7 \%(48)$ & $18.2 \%(12)$ & $9.1 \%(6)$ & $27.3 \%(18)$ \\
\hline $\begin{array}{l}\text { Nunca antes había visto a un doctor. (I had never before seen a doc- } \\
\text { tor.) }\end{array}$ & $72.7 \%(48)$ & $12.1 \%(8)$ & $15.2 \%(10)$ & $27.3 \%(18)$ \\
\hline $\begin{array}{l}\text { No podía obtener permiso en el trabajo. (I could not get time off } \\
\text { from work.) }\end{array}$ & $75.8 \%(50)$ & $19.7 \%(13)$ & $4.5 \%(3)$ & $24.2 \%(16)$ \\
\hline $\begin{array}{l}\text { He tenido experiencias negativas con proveedores médicos en el } \\
\text { pasado y me resisto a buscar atención. (I have had negative experi- } \\
\text { ences with medical providers in the past and am reluctant to seek } \\
\text { care.) }\end{array}$ & $77.3 \%(51)$ & $18.2 \%(12)$ & $4.5 \%(3)$ & $22.7 \%(15)$ \\
\hline $\begin{array}{l}\text { No contaba con servicio de cuidado infantil. (I had no child care } \\
\text { (daycare, } n=48 \text { ) }\end{array}$ & $89.6 \%(43)$ & $8.3 \%(4)$ & $2.1 \%(1)$ & $10.4 \%(5)$ \\
\hline
\end{tabular}

${ }^{*} \mathrm{n}=66$ unless otherwise noted

get out of the shadows and join the legal workforce, positioning this group to feel more empowered in their day to day lives [29].
Ongoing research is needed to explore and document the social and health ramifications of economic immigration. Our attempt to understand concerns focused more heavily on 
those related to premigration and journey and then barriers to engaging in HIV care. More research, ideally qualitative, is needed to better understand the entirety of intrapersonal, social and health challenges immigrants and sexual minorities face while navigating U.S. communities. Further, additional research is needed in the design and evaluation of preventive interventions pre and postmigration to bolster mental and sexual health, reduce stigma, reduce transmission of HIV, as well as increase awareness of the importance of routine testing and timely engagement in care. Nearly one quarter of the sample did not identify with any of the sexual orientation options in the survey (heterosexual, derecho, straight; homosexual, gay, bisexual, otro). This lack of identification was more likely for those screening positive for depression. Future research could explore meaning, saliency, and emic language relating to sexual orientation.

One significant limitation of this study was the lack of nuanced data that could have been garnered through a qualitative study. This study sheds light on broad social and structural barriers to care for Mexican born men living with HIV in Chicago, but a follow-up study inclusive of in-depth interviews exploring the stories of these individual participants would provide more depth and further our understanding of the barriers to HIV care and retention for this group. Additionally, these findings cannot be generalized to Mexicans as a whole, as the subpopulation in this study was specific to the experiences of Mexican born men living with HIV in Chicago who access care at a safety net public health clinic.

\section{New Contribution to the Literature}

This study uniquely describes the social characteristics and barriers to HIV care and retention for Mexican born/ immigrant men living in Chicago. Given that the rates of HIV continue to rise among Latinx communities across the United States and specifically, Mexican men in Chicago, understanding these characteristics and barriers is important to curbing the epidemic among this subpopulation. More prevention and intervention research and action are needed to ameliorate the negative socioeconomic and health ramifications of economic immigration and bolster the mental and sexual health, reduce transmission of HIV, and increase testing, linkage, engagement and retention in HIV care.

Supplementary Information The online version contains supplementary material available at https://doi.org/10.1007/s10903-021-01158-y.

Acknowledgements The authors thank the individuals who participated in this study and we honor their resiliency in the face of incredible challenges. We would also like to thank the intervention team who were extremely committed to this project: Naomi Jimenez, Monica Puente and Elena Vertti. This project was supported by the Health Resources and Services Administration (HRSA) of the U.S. Department of Health and Human Services (HHS) under grant number H97HA26503. The content and conclusions are those of the authors and should not be construed as the official position or policy of, nor should any endorsements be inferred by the HRSA, HHS or U.S. Government.

Open Access This article is licensed under a Creative Commons Attribution 4.0 International License, which permits use, sharing, adaptation, distribution and reproduction in any medium or format, as long as you give appropriate credit to the original author(s) and the source, provide a link to the Creative Commons licence, and indicate if changes were made. The images or other third party material in this article are included in the article's Creative Commons licence, unless indicated otherwise in a credit line to the material. If material is not included in the article's Creative Commons licence and your intended use is not permitted by statutory regulation or exceeds the permitted use, you will need to obtain permission directly from the copyright holder. To view a copy of this licence, visit http://creativecommons.org/licenses/by/4.0/.

\section{References}

1. Centers for Disease Control and Prevention. Estimated HIV incidence and prevalence in the United States, 2014-2018. HIV Surveillance Supplemental Report 2020;25(No. 1). https://www. cdc.gov/hiv/pdf/library/reports/surveillance/cdc-hiv-surveillancesupplemental-report-vol-25-1.pdf. Published May 2020. Accessed 1 July 2020.

2. Centers for Disease Control and Prevention. Estimated HIV incidence and prevalence in the United States, 2010-2016. HIV surveillance supplemental report 2019; 24 (No. 1). https://www. cdc.gov/hiv/pdf/library/reports/surveillance/cdc-hiv-surveillan ce-supplemental-report-vol-24-1.pdf?source=npin_highlight. Published February 2019. Accessed 10 July 2019.

3. Centers for Disease Control and Prevention (CDC). State HIV prevention progress report, 2019. Atlanta, GA

4. Chicago Department of Public Health (CDPH). STI/HIV surveillance report, 2019. Chicago, IL: City of Chicago; 2019

5. Dietz P.M., Krueger A.L., Wolitski R.J. et al. State HIV prevention progress report, 2014 http://www.cdc.gov/hiv/policies/progressre ports/index.html. Published August 2014. Accessed 10 July 2019.

6. Bhatia R, Hartman C, Kallen MA, Graham J, Giordano TP. Persons newly diagnosed with HIV infection are at high risk for depression and poor linkage to care: Results from the Steps Study. AIDS Behav. 2011;15(6):1161-70.

7. Levison JH, Bogart LM, Khan IF, Mejia D, Amaro H, Alegría M, Safren S. "Where It Falls Apart": Barriers to retention in HIV care in Latino immigrants and migrants. AIDS Patient Care STDs. 2017;31(9):394-405.

8. Kutner BA, Nelson KM, Simoni JM, Sauceda JA, Wiebe JS. Factors associated with sexual risk of HIV transmission among HIVpositive Latino men who have sex with men on the US-Mexico border. AIDS Behav. 2017;21(3):923-34.

9. Zhang X, Rhoads N, Rangel MG, Hovell MF, Magis-Rodriguez C, Sipan CL, Gonzalez-Fagoaga JE, Martínez-Donate AP. Understanding the impact of migration on HIV risk: An analysis of Mexican migrants' sexual practices, partners, and contexts by migration phase. AIDS Behav. 2017;21(3):935-48.

10. Mann L, Valera E, Hightow-Weidman LB, Barrington C. Migration and HIV risk: Life histories of Mexican-born men living with HIV in North Carolina. Culture Health Sex. 2014;16(7):820-34.

11. Viruell-Fuentes EA, Miranda PY, Abdulrahim S. More than culture: Structural racism, intersectionality theory, and immigrant health. Soc Sci Med. 2012;75(12):2099-106. 
12. Dang BN, Giordano TP, Kim JH. Sociocultural and structural barriers to care among undocumented Latino immigrants with HIV infection. J Immigr Minor Health. 2012;14:124-31.

13. Levison JH, Levinson JK, Alegría M. A critical review and commentary on the challenges of engaging HIV-infected Latinos in the continuum of HIV care. AIDS Behav. 2018;22:2500-12.

14. Stangl AL, Lloyd JK, Brady LM, Holland CE, Baral SA. A systematic review of interventions to reduce HIV-related stigma and discrimination from 2002 to 2013: How far have we come? J Int AIDS Soc. 2013;16(3):18734.

15. Bronfenbrenner U. The ecology of human development: Experiments by nature and design. Cambridge, MA: Harvard University Press; 1979.

16. Cervantes RC, Padilla AM, Salgado de Snyder N. The Hispanic stress inventory: A culturally relevant approach to psychosocial assessment. Psychol Assess. 1991;3:438-47.

17. Eastwood EA, Fletcher J, Quinlivan EB, Verdecias N, Birnbaum JM, Blank AE. Baseline social characteristics and barriers to care from a special projects of national significance women of color with HIV study: A comparison of urban and rural women and barriers to HIV care. AIDS Patient Care STDS. 2015;29(S1):S4-10.

18. Cameron RP, Gusman D. The Primary Care PTSD screen (PCPTSD): Development and operating characteristics (PDF). Primary Care Psychiatry. 2003;9:9-14.

19. Radloff LS. The CES-D scale: A self-report depression scale for research in the general population. Appl Psychol Meas. 1977;1(3):385-401.

20. Ewing JA. Detecting alcoholism: The CAGE questionnaire. JAMA. 1984;252(14):1905-7.

21. Magis-Rodriguez C, Lemp G, Hernandez MT, Sanchez MA, Estrada F, Bravo-Garcia E. Going North: Mexican migrants and their vulnerability to HIV. J Acquir Immune Defic Syndr. 2009;51:S21-5.

22. Herman JL. Trauma and recovery: The aftermath of violencefrom domestic abuse to political terror. Hachette UK: Basic Book; 2015.
23. Van der Kolk BA. The body keeps the score: Brain, mind, and body in the healing of trauma. New York: Penguin Books; 2015.

24. Tanner AE, Reboussin BA, Mann L, Ma A, Song E, Alonzo J, Rhodes SD. Factors influencing health care access perceptions and care-seeking behaviors of immigrant Latino sexual minority men and transgender individuals: Baseline findings from the HOLA intervention study. J Health Care Poor Underserved. 2014;25(4):1679.

25. Rhodes SD, Hergenrather KC, Zometa C, Lindstrom K, Montano $\mathrm{J}$. Characteristics of immigrant Latino men who use formal health care services: Baseline findings from the HoMBReS study. J Natl Med Assoc. 2008;100(10):1177-85.

26. Parrado EA, Flippen CA. Migration and sexuality: A comparison of Mexicans in sending and receiving communities. J Soc Issue. 2010;66(1):175-95.

27. Dennis AM, Wheeler JB, Valera E, Hightow-Weidman L, Napravnik S, Swygard H, Barrington C, Eron JJ. HIV risk behaviors and sociodemographic features of HIV-infected Latinos residing in a new Latino settlement area in the Southeastern United States. AIDS Care. 2013;25(10):1298-307.

28. Organista KC, Arreola SG, Neilands TB. La desesperación in Latino migrant day laborers and its role in alcohol and substancerelated sexual risk. SSM-Population Health. 2016;2:32-42.

29. Galeucia M, Hirsch JS. State and local policies as a structural and modifiable determinant of HIV vulnerability among Latino migrants in the United States. Am J Public Health. 2016;106(5):800-7.

Publisher's Note Springer Nature remains neutral with regard to jurisdictional claims in published maps and institutional affiliations. 